\title{
Corporate Governance, Ukuran Perusahaan, Asimetri Informasi dan Manajemen Laba
}

\author{
Adelphia Christian Wibowo ${ }^{1}$ \\ Maria Mediatrix Ratna Sari ${ }^{2}$ \\ 1,2Fakultas Ekonomi dan Bisnis Universitas Udayana, Indonesia \\ ${ }^{*}$ Correspondences : adelphia.cw@gmail.com
}

\begin{abstract}
ABSTRAK
Penelitian dilakukan dengan tujuan menemukan bukti empiris mengenai manajemen laba yang dipengaruhi corporate governance, ukuran perusahaan dan asimetri informasi. Penelitian melibatkan 100 perusahaan manufaktur yang tercatat di BEI tahun 2017-2019 dengan 300 sampel amatan. Hasil analisis penelitian ditemukan keberadaan wanita dalam jajaran dewan direksi, dewan komisaris dan komite audit belum mampu meminimalisir praktik manajemen laba. Semakin besar ukuran suatu perusahaan dan asimetri informasi yang terjadi maka semakin besar pula kemungkinan praktik manajemen laba yang dilakukan perusahaan.
\end{abstract}

Kata Kunci: Corporate Governance; Ukuran Perusahaan; Asimetri Informasi; Manajemen Laba.

\section{Corporate Governance, Company Size, Information Asymmetry and Earnings Management}

\begin{abstract}
The research was conducted with the aim of finding empirical evidence regarding earnings management that is influenced by corporate governance, firm size and information asymmetry. The study involved 100 manufacturing companies listed on the Indonesia Stock Exchange in 2017-2019 with 300 samples of observation. The results of the research analysis found that the presence of women on the board of directors, commissioners and audit committees has not been able to minimize earnings management practices. The larger the size of a company and the information asymmetry that occurs, the greater the possibility of earnings management practices carried out by the company.
\end{abstract}

Keywords: Corporate Governance; Company Size; Information Asymmetry; Earnings Management.

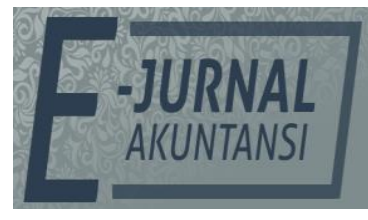

e-ISSN 2302-8556

Vol. 32 No. 2

Denpasar, Februari 2022

Hal. 325-337

DOI:

10.24843/EJA.2022.v32.i02.p04

PENGUTIPAN:

Wibowo, A. C. \& Sari, M. M.

R. (2022). Corporate

Governance, Ukuran

Perusahaan, Asimetri

Informasi dan Manajemen

Laba. E-Jurnal Akuntansi,

32(2), 325-337

RIWAYAT ARTIKEL:

9 Juni 2021

Artikel Diterima:

31 Desember 2021

Artikel dapat diakses : https://ojs.unud.ac.id/index.php/Akuntansi/index 


\section{PENDAHULUAN}

Informasi laba dalam laporan keuangan dapat digunakan untuk menilai kekuatan perusahaan dalam menghasilkan laba di masa mendatang oleh pemilik atau pihak lain seperti kreditur dan investor. Untuk itu pihak manajemen cenderung memilih kebijakan keuangan yang menghasilkan laporan keuangan terbaik kepada pemilik perusahaan. Manajemen laba adalah suatu intervensi dalam proses penyusunan laporan keuangan yaitu dengan meratakan, menaikkan, dan menurunkan laba yang dilakukan oleh manajer (Schipper, 1986).

Manajemen laba yang dilakukan oleh perusahaan tidak terlepas dari konsep teori agensi. Teori agensi merupakan teori yang melandasi hubungan keagenan antara prinsipal dengan agen Jensen \& Meckling (1976) mendefinisikan hubungan keagenan sebagai suatu kontrak antara principal dengan agen untuk menjalankan tugas atas nama pemilik, dimana agen diberikan kewenangan dalam pengambilan keputusan.

Praktik manajemen laba pernah terjadi pada PT. Kimia Farma Tbk dengan melakukan markup laba bersih dan PT Lippo dengan menerbitkan tiga laporan keuangan yang berbeda dalam laporan keuangannya. Adanya manajemen pada suatu perusahaan merupakan indikasi dari masalah keagenan yang terjadi karena perbedaan kepentingan diantara manajer perusahaan (agent) dan pemegang saham (principal). Pemegang saham termotivasi mengadakan kontrak dengan profitabilitas yang selalu meningkat untuk mensejahterakan dirinya sedangkan manajer perusahaan termotivasi untuk memaksimalkan pemenuhan kebutuhan ekonomi dan psikologisnya, antara lain dalam hal memperoleh investasi, pinjaman, maupun kontrak kompensasi (Prasetyo, 2018).

Perilaku manajer yang melakukan praktik manajemen laba dapat diminialisir dengan penerapan Corporate Governance. Corporate Governance merupakan seperangkat peraturan yang mengatur hubungan antara pemegang, pengurus, pihak kreditur, pemerintah, karyawan, serta para pemegang kepentingan internal dan eksternal lainnya yang berkaitan dengan hak-hak dan kewajiban mereka atau dengan kata lain suatu sistem yang mengendalikan perusahaan (FCGI, 2001). Dalam Corporate Governance, dewan direksi bertanggungjawab dan menandatangani laporan keuangan. Sedangkan dewan komisaris dan komite audit terlibat dalam memastikan integritas dan kualitas laporan keuangan.

Isu gender dalam manajemen puncak menjadi topik yang menarik untuk diteliti. Gender sendiri merupakan suatu konsep yang digunakan untuk mengidentifikasi perbedaan laki-laki dan perempuan dari sudut non biologis. Hal ini berbeda dengan seks yang secara umum digunakan untuk mengidentifikasi perbedaan laki-laki dan perempuan dari segi anatomi biologis (Arbain at al. 2015). Menurut Tierney (1999) gender adalah suatu konsep kultural yang berupaya membuat pembedaan dalam hal perilaku, peran, metalitas, dan karakteristik emosional antara laki-laki dan perempuan yang berkembang dalam masyarakat. Louann Brizendine (2010:9) mengatakan bahwa emosi wanita dan pria akan berbeda dikarenakan adanya perbedaan struktur otak dan hormon yang ada pada wanita dan pria itu sendiri Keberadaan wanita dalam jajaran dewan direksi, dewan komisaris, dan komite audit sebagai bagian dari corporate goverance dianggap memberikan pengaruh pada praktik manajemen laba. Berdasarkan role congruity theory towards female leaders (Eagly \& Karau, 2002) karakteristik laki-laki 
dikategorikan sebagai agentik, yaitu tegas, percaya diri, dan berkuasa; sementara karakteristik perempuan adalah komunal, seperti menyenangkan orang lain, atraktif dan dapat dipercaya. Sifat agentic umumnya diartikan bahwa laki- laki lebih banyak memiliki sifat sebagai pemimpin, dibandingkan perempuan. Akibatnya, perempuan cenderung tidak diangkat sebagai pemimpin dibandingkan laki-laki karena stereotip laki-laki adalah sebagai pemimpin. Namun World Economic Forum membuat laporan dengan judul The Global Gender Gap Report 2020 (World Economic Forum, 2019) menyatakan bahwa 55\% kepemimpinan di Indonesia dipegang oleh wanita dan menjadi salah satu dari enam negara di dunia yang mayoritas peran kepemimpinannya dipegang oleh wanita. Hal ini menjadi hal yang unik karena wanita yang lebih bersifat komunal ternyata mampu mendominasi kepemimpinan di Indonesia.

Dengan perbedaan gender tersebut, pria dan wanita akan bertindak atau memiliki respons yang berbeda dalam menghadapi masalah yang sama. Penelitian yang dilakukan Peni \& Vähämaa (2010) mengatakan bahwa pria dan wanita akan bertindak berbeda dalam menghadapi kondisi yang sama misalnya dalam hal gaya kepemimpinan, gaya berkomunikasi, konservatisme, menghindari resiko dan pengambilan keputusan. Wanita cenderung beretika dibanding dengan pria.

Penelitian yang dilakukan oleh Gavious et al. (2012) menunjukan bahwa keberadaan salah satu dari wanita dalam dewan direksi berhubungan secara signifikan pada tingkat manajemen laba yang lebih rendah dan wanita cenderung beretika dalam membuat pertimbangan dibanding pria serta keberadaan wanita dalam dewan direksi akan memberikan hambatan pada praktik manajemen laba karena adanya keterlibatan isu gender didalamnya. Dengan demikian ketika sebuah perusahaan dalam keanggotaan dewan direksi terdapat peran serta wanita maka ada kemungkinan penurunan tingkat manajemen laba pada perusahaan tersebut.

$\mathrm{H}_{1}$ : Keberadaan wanita dalam dewan direksi berpengaruh negatif signifikan terhadap manajemen laba.

Penelitian yang dilakukan oleh Gul et al. (2011) menguji pengaruh komisaris wanita terhadap kualitas laba di Amerika Serikat. Penelitian mereka menunjukkan bahwa perusahaan Amerika Serikat dengan tingkat keberagaman gender dewan yang lebih tinggi memiliki kualitas laporan yang lebih baik dan kecil kemungkinannya untuk melakukan manajemen laba. Sifat wanita yang lebih konservatif, menghindari risiko, dan memiliki standar etika yang lebih tinggi merupakan salah satu faktor yang dapat menjadi penyebab hubungan negatif antara keberadaan wanita dalam dewan komisaris dengan manajemen laba. Untuk itu, dewan komisaris wanita yang pada dasarnya memiliki sifat feminim dianggap dapat mengurangi manajemen laba, karena lebih konservatif dan menghindari risiko terkait investasi keuangan yang dapat mengarah pada kewaspadaan dewan dalam pemantauan laporan keuangan.

$\mathrm{H}_{2}$ : Keberadaan wanita dalam dewan komisaris berpengaruh negatif signifikan terhadap manajemen laba.

Penelitian Sun \& Liu (2014) dan Na \& Hong (2017) menyatakan bahwa anggota perempuan dalam komite audit cenderung meningkatkan kinerja perusahaan dan mengurangi risiko serta menghindari risiko. Dengan demikian, 
keanggotaan wanita dalam komite audit diharapkan akan mampu menurunkan tingkat manajemen laba.

$\mathrm{H}_{3}$ : Keberadaan wanita dalam komite audit berpengaruh negatif signifikan terhadap manajemen laba.

Selain perbedaan gender dalam manajemen puncak ukuran perusahaan juga memberikan pengaruh terhadap praktik manjemen laba. Ukuran perusahaan yang lebih besar cenderung memiliki kompleksitas operasi dan kebutuhan pendanaan yang tinggi, sehingga mengakibatkan basis pemegang kepentingan perusahaan semakin luas pula. Dimana hal tersebut menyebabkan tekanan pada perusahaan untuk menyajikan laporan keuangan yang dapat dipercaya semakin kuat pula, hal ini dapat memicu manajer untuk melakukan manajemen laba guna mnyajikan informasi yang sesuai dengan ekspektasi para pemangku kepentingan perusahaan (Lupita \& Meiranto, 2019). Penelitian yang dilakukan Ali et al. (2015), Medyawati \& Dayanti (2016) serta Ronikusuma \& Hadiprajitno (2019) menyatakan bahwa ukuran perusahaan berpengaruh positif dan signifikan terhadap manajemen laba.

$\mathrm{H}_{4}$ : Ukuran perusahaan berpengaruh positif signifikan terhadap majemen laba.

Selain dipengaruhi oleh ukuran perusahaan, manajemen laba juga terjadi akibat adanya asimetri informasi yang terjadi antara prinsipal dengan agen. Agen lebih banyak mengetahui informasi dalam perusahaan hingga peluang keuntungan perusahaan yang tidak diketahui oleh prinsipal. Dengan adanya ketimpangan informasi yang dimiliki oleh agen maka dapat memicu agen memilih kebijakan akuntansi yang dapat memaksimalkan laba kepada pemilik perusahaan yang tidak sesuai dengan kondisi perusahaan yang sebenarnya. Penelitian yang dilakukan oleh Mahawyahrti \& Budiasih (2017) menyatakan bahwa asimetri informasi berpengaruh signifikan terhadap praktik manajemen laba.

$\mathrm{H}_{5}$ : Asimetri informasi berpengaruh positif signifikan terhadap majemen laba.

Industri manufaktur dipilih sebagai objek penelitian ini karena industri dengan perusahaan yang paling banyak terdaftar di BEI. Perusahaan manufaktur lebih banyak membutuhkan sumber dana jangka panjang untuk membiayai kegiatan operasi perusahaan.

\section{METODE PENELITIAN}

Penelitian ini dilakukan pada perusahaan manufaktur yang terdaftar di Bursa Efek Indonesia periode 2017-2019. Obyek penelitian dalam penelitian ini adalah manajemen laba pada perusahaan manufaktur yang terdaftar di Bursa Efek Indonesia periode 2017-2019.

Manajemen laba adalah suatu kondisi dimana manajemen melakukan intervensi dalam proses penyusunan laporan keuangan bagi pihak eksternal sehingga dapat meratakan, menaikkan, dan menurunkan laba (Schipper 1986). Pengukuran manajemen laba menggunakan Discretionary Accrual (DAC). Dalam penelitian ini discretionary accrual digunakan sebagai proksi karena merupakan komponen yang dapat dimanipulasi oleh manajer seperti penjualan kredit. Untuk mengukur DAC dengan menggunakan Modified Jones Model Dechow et al. (1995). Model ini lebih baik dibanding model Jones Standard dalam mengukur kasus manipulasi pendapatan. Model perhitungannya adalah terlebih dahulu akan 
mengukur total akrual. Menurut Midiastuty (2003) total akrual diklasifikasikan menjadi komponen discretionary dan nondiscretionary, dengan tahapan berikut.

$\mathrm{TAC}=\mathrm{NI}-\mathrm{CFO}$.

$\frac{T A C}{T A}-1=\beta 1\left(\frac{1}{T A}-1\right)+\beta 2\left(\frac{R E V-R E C}{T A}-1\right)+\beta 3\left(\frac{P P E}{T A}-1\right)+$

$\mathrm{NDTAC}=\beta 1+\left(\frac{1}{T A}-1\right)+\beta 2+\left(\frac{R E V-R E C}{T A}-1\right)+\beta 3\left(\frac{P P E}{T A}-1\right)+\varepsilon$

DTAC $=\left(\frac{T A C}{T A}-1\right)-N D T A C$

Keterangan:

DTAC = Discretionary Accruals

NDTAC = Nondiscretionary Accruals

NI $\quad=$ Net Income

TAC $\quad=$ Total Accruals

$\mathrm{CFO} \quad=$ Aliran Arus

TA $\quad=$ Total Aktiva Periode Sebelumnya

REV $\quad=$ Perubahan Pendapatan Perusahaan

PPE $\quad=$ Aktiva Tetap Perusahaan

REC $\quad=$ Perubahan Piutang

Ukuran variabel dewan direksi wanita dihitung menggunakan presentase dari jumlah dewan direksi wanita terhadap jumlah keseluruhan dewan direksi (Octaviani \& Kartikaningdyah, 2019). Perhitungan variabel ini adalah sebagai berikut.

DDW $=\frac{\sum \text { Dewan Direksi Wanita }}{\sum \text { Dewan Direksi }} \times 100 \%$

Ukuran variabel dewan komisaris wanita dihitung menggunakan persentase dari jumlah dewan komisaris wanita terhadap jumlah keseluruhan dewan komisaris (Octaviani \& Kartikaningdyah, 2019) Perhitungan variabel ini adalah sebagai berikut.

DKW $=\frac{\sum \text { Dewan Komisaris Wanita }}{\sum \text { Dewan Komisaris }} \times 100 \%$.

Ukuran variabel komite audit wanita dihitung menggunakan persentase dari jumlah komite audit wanita terhadap jumlah keseluruhan komite audit (Octaviani \& Kartikaningdyah, 2019). Perhitungan variabel ini adalah sebagai berikut.

DKW $=\frac{\sum \text { Komite Audit Wanita }}{\sum \text { Komite Audit }} \times 100 \%$

Ukuran perusahaan diukur dengan melihat besarnya aset yang dimiliki sebuah perusahaan. Ukuran perusahaan diukur dari total aktiva kemudian ditransformasikan dalam bentuk logaritma natural dengan tujuan untuk memperhalus data. Ukuran perusahaan dapat diukur dengan rumus (Hartono, 2007: 282)

Firm Size $=$ Ln total aktiva perusahaan

Asimetri informasi diukur dengan menggunakan relative bid-ask spread, dimana asimetri informasi dilihat dari selisih harga saat ask dengan harga bid saham perusahaan atau selisih harga jual dan harga beli saham perusahaan selama satu tahun. Perhitungan model yang digunakan adalah sebagai berikut (Healy \& Wahlen 1999).

$S P R E A D=((a s k-b i d) /((a s k+b i d) / 2) \times 100)$ 
Keterangan:

SPREAD = Selisih harga ask dengan harga bid selama 1 tahun

Ask $\quad=$ Harga ask tertinggi saham perusahaan selama 1 tahun

Bid = Harga bid terendah saham perusahaan selama 1 tahun

Leverage adalah kemampuan perusahaan untuk membayar utangutangnya baik utang jangka pendek maupun utang jangka panjangnya, atau dengan kata lain seberapa besar kegiatan operasi perusahaan yang didanai dari utang (Wiagustini 2014:76). Dalam penelitian ini leverage diukur dengan menggunakan Debt to Asset Ratio (DAR) karena dapat mengukur seberapa besar perusahaan mengandalkan utang untuk membiayai asetnya. DAR dalam penelitian ini dihitung dengan menggunakan rumus sebagai berikut.

Leverage $(L E V)=\frac{\text { Total Kewajiban }}{\text { Total Ekuitas }}$

Populasi dalam penelitian ini adalah perusahaan manufaktur yang terdaftar di Bursa Efek Indonesia dari tahun 2017-2019 yang dapat diakses melalui website idx. Perusahaan manufaktur digunakan dalam penelitian ini karena sektor manufaktur memiliki aggota perusahaan yang lebih banyak dibandingkan dengan sektor lainnya. Sampel akan diambil dari populasi tersebut berdasarkan pendekatan nonprobabilitas menggunakan metode purposive sampling.

Tabel 1. Perusahaan Manufaktur yang Menjadi Sampel Penelitian Berdasarkan Kriteria Pengambilan Sampel

\begin{tabular}{clc}
\hline No & \multicolumn{1}{c}{ Keterangan } & Jumlah \\
\hline 1 & $\begin{array}{l}\text { Perusahaan manufaktur yang terdaftar di BEI periode 2017-2019 } \\
2\end{array}$ & $\begin{array}{l}\text { Perusahaan yang menyediakan laporan tahunan dan laporan keuangan } \\
\text { di BEI periode 2017-2019 }\end{array}$ \\
3 & $\begin{array}{l}\text { Perusahaan yang tidak melakukan delisting selama 2017-2019 } \\
4\end{array}$ & 144 \\
& $\begin{array}{l}\text { Perusahaan yang menerbitkan laporan keuangan } \\
\text { tahunan dengan menggunakan nilai mata uang rupiah }\end{array}$ & 114 \\
5 & $\begin{array}{l}\text { Perusahaan yang mempublikasikan data secara lengkap terkait dengan } \\
\text { variabel yang digunakan dalam penelitian ini }\end{array}$ & 100 \\
$\quad \begin{array}{l}\text { Jumlah sampel terseleksi } \\
\text { Total sampel dalam 3 tahun penelitian }\end{array}$ & 100 \\
\hline
\end{tabular}

Sumber: Data Penelitian, 2021

Teknik analisis regresi linier berganda digunakan dalam penelitian ini dengan model sebagai berikut:

$Y=\alpha+\beta 1 X 1+\beta 2 X 2+\beta 3 X 3+\beta 4 X 4+\beta 5 X 5+\beta 6 X 6+\varepsilon$

Keterangan:

Y

a

$\beta_{1}, \beta_{2}, X_{1}$

$\beta_{3,}, \beta_{4}, \beta_{5}, \beta_{6}$

$\mathrm{X}_{2}$

$x_{3}$

$\mathrm{X}_{4}$

$X_{5}$

$\mathrm{X}_{6}$

$\varepsilon$
= Manajemen Laba

= Nilai Intersep Konstanta

= Dewan Direksi Wanita

$=$ Koefisien regresi variabel $\mathrm{X}_{1}, \mathrm{X}_{2}, \mathrm{X}_{3}, \mathrm{X}_{4}, \mathrm{X}_{5}, \mathrm{X}_{6}$

= Dewan Komisaris Wanita

= Komite Audit Wanita

= Ukuran Perusahaan

= Asimetri Informasi

$=$ Leverage

= Standard Error 


\section{HASIL DAN PEMBAHASAN}

Hasil uji statistik deskriptif dalam penelitian ini disajikan pada Tabel 2, untuk memberikan informasi tentang karakteristik proksi dari variabel penelitian.

\section{Tabel 2. Statistik Deskriptif}

\begin{tabular}{lccccc}
\hline Variable & $\mathrm{N}$ & Minimum & Maximum & Mean & Std. Deviation \\
\hline DDW & 300 & 0,0 & 100,0 & 12,687 & 19,174 \\
DKW & 300 & 0,0 & 75,0 & 10,457 & 17,346 \\
KAW & 300 & 0,0 & 66,7 & 19,311 & 23,403 \\
FirmSize & 300 & 25,215 & 33,494 & 28,450 & 1,586 \\
SPREAD & 300 & 3,921 & 180,124 & 48,152 & 30,315 \\
LEV & 300 & $-10,188$ & 786,931 & 3,894 & 45,423 \\
DA & 300 & $-1,437$ & 4,841 & 0,054 & 0,444 \\
\hline
\end{tabular}

Sumber: Data Penelitian, 2021

Keterangan: DDW= dewan direksi wanita, DKW = dewan komisaris wanita, KAW

$=$ komite audit wanita, Firm Size $=$ ukuran perusahaan, SPREAD $=$ asimetri informasi, LEV = leverage, DA = Manajemen Laba.

Sebelum model regresi digunakan, perlu Autokorelasi, Uji Multikolinieritas, Uji menguji kelayakan model. Untuk itu dilakukan Heteroskedastisitas dan Uji Normalitas. Tabel 3. Menyajikan hasil uji.

Tabel 3. Hasil Uji Asumsi Klasik

\begin{tabular}{lccc}
\hline \multirow{2}{*}{ Variable } & \multicolumn{2}{c}{ Collinearity Statistics } & Signification \\
\cline { 2 - 3 } (Constant) & Tolerance & VIF & \\
DDW & 0,428 & 2,000 \\
DKW & 0,247 & 4,049 & 0,226 \\
KAW & 0,515 & 1,942 & 0,111 \\
FirmSize & 0,209 & 4,794 & 0,513 \\
SPREAD & 0,132 & 7,567 & 0,683 \\
LEV & 0,996 & 1,004 & 0,974 \\
Asymp. Sig. (2 tailed) & - & - & 0,316 \\
Durbin-Watson & - & - & 0,376 c, \\
Run Test & - & - & 1,171 \\
Sumber: Data Penelitan & 2021 & & 0,999 \\
\hline
\end{tabular}

Sumber: Data Penelitian, 2021

Uji normalitas bertujuan untuk menguji apakah model regresi, variabel pengganggu atau residual mempunyai distribusi normal atau tidak. Model regresi yang baik adalah model regresi yang terdistribusi normal. Berdasarkan hasil pengujian pada Tabel 3, diperoleh nilai Asymp sig K-S sebesar 0,376 lebih besar dari 0,05 . Hal ini menunjukkan bahwa data dalam model regresi telah terdistribusi normal.

Uji autokorelasi adalah pengujian yang dilakukan untuk mengetahui hubungan yang terjadi di antara anggota dari serangkaian pengamatan yang tersusun pada rangkaian waktu. Untuk mengetahui ada tidaknya autokorelasi, maka digunakan metode Durbin-Watson (DW-test). Nilai DW-test selanjutnya dibandingkan dengan nilai tabel DW menggunakan tingkat signifikansi 5 persen.

Berdasarkan Tabel 3, dapat dilihat bahwa nilai $\mathrm{dL}=1,783$ dan $\mathrm{dU}=1,837$ sehingga diperoleh nilai 4-dU $=2,162$, maka dapat dirumuskan kriteria $\mathrm{dU}<\mathrm{DW}$ $<4$-dU yaitu 1,837<1,171 <2,162. Hal ini menunjukkan tidak adanya kesimpulan yang jelas mengenai hasil uji autokorelasi yang dilakukan dengan menggunakan 
uji Durbin Watson karena 4-dU $\leq \mathrm{DW} \leq 4$-dL yaitu $2,162 \leq 1,171 \leq 2,216$. Peneliti mengatasi masalah autokorelasi dengan menggunakan uji autokorelasi lainnya yaitu Run Test. nilai Asymp. Sig (2-tailed) sebesar 0,999 maka Asymp. Sig (2-tailed) lebih besar dari 0,005 $(0,999>0,005)$. Hal ini menunjukkan bahwa nilai residual acak atau random, sehingga dapat disimpulkan bahawa pada penelitian ini tidak terjadi autokorelasi antar nilai residual.

Berdasarkan hasil pengujian pada Tabel 3, menunjukkan bahwa semua variabel independen mempunyai nilai tolerance diatas 0,1 dan nilai VIF dibawah 10. Hal ini menunjukkan bahwa tidak terjadi gejala multikolinieritas dalam model regresi ini.

Berdasarkan hasil penelitian yang ditunjukkan pada Tabel 3, dapat dilihat bahwa tingkat signifikansi dari masing-masing variabel bebas memiliki tingkat signifikansi lebih dari 0,05. Hal ini berarti model regresi yang diujikan bebas dari gejala heteroskedastisitas. Berdasarkan perhitungan dengan bantuan program SPSS 25, maka hasil analisis regresi linear berganda disajikan pada Tabel 4 .

\section{Tabel 4. Analisis Regresi Linear}

\begin{tabular}{lccccc}
\hline \multirow{2}{*}{ Model } & \multicolumn{2}{c}{$\begin{array}{c}\text { Unstandardized } \\
\text { Coefficients }\end{array}$} & $\begin{array}{c}\text { Standardized } \\
\text { Coefficients }\end{array}$ & $\mathrm{t}$ & Signification \\
\cline { 2 - 4 } & $\mathrm{B}$ & Std. Error & Beta & & \\
\hline (Constant) & $-0,067$ & 0,023 & & $-2,889$ & 0,004 \\
DDW & 0,144 & 0,048 & 0,213 & 2,992 & 0,003 \\
DKW & 0,107 & 0,036 & 0,275 & 2,934 & 0,004 \\
KAW & 0,345 & 0,047 & 0,480 & 7,404 & 0,000 \\
FirmSize & 0,409 & 0,051 & 0,824 & 8,087 & 0,000 \\
SPREAD & 0,103 & 0,032 & 0,416 & 3,252 & 0,001 \\
LEV & 0,005 & 0,046 & 0,005 & 0,100 & 0,920 \\
Fhitung & - & - & - & - & 28,066 \\
Sig. Fhitung & - & - & - & - & 0,000 \\
Adjusted R & - & - & - & - & 0,352 \\
\hline
\end{tabular}

Sumber: Data Penelitian, 2021

Berdasarkan Tabel 4, dapat dibentuk persamaan regresi linear berganda sebagai berikut.

$\mathrm{Y}=0,067+0,144 \mathrm{DDW}+0,107 \mathrm{DKW}+0,345 \mathrm{KAW}+$ 0,409FirmSize + 0,103SPREAD $+0,005 \mathrm{LEV}$.

Konstanta sebesar -0,067 menunjukkan jika variabel bebas dianggap konstan atau sama dengan nol, maka nilai manajemen laba sebesar -0,067 satuan. Nilai koefisien variabel dewan direksi wanita (DDW) sebesar 0,144 menunjukan bahwa jika dewan direksi wanita (DDW) naik sebesar satu satuan, sementara varaibel lainnya diasumsikan tetap, maka variabel manajemen laba (Y) akan mengalami peningkatan sebesar 0,144 satuan. Nilai koefisien variabel dewan komisaris wanita (DKW) sebesar 0,107 menunjukan bahwa jika dewan komisaris wanita (DKW) naik sebesar satu satuan, sementara varaibel lainnya diasumsikan tetap, maka manajemen laba (Y) akan mengalami peningkatan sebesar 0,107 satuan. Nilai koefisien variabel komite audit wanita (KAW) sebesar 0,345 menunjukan bahwa jika komite audit wanita (KAW) naik sebesar satu satuan, sementara varaibel lainnya diasumsikan tetap, maka manajemen laba (Y) akan mengalami peningkatan sebesar 0,345 satuan. 
Nilai koefisien variabel ukuran perusahaan (FirmSize) sebesar 0,409 menunjukan bahwa jika ukuran perusahaan (FirmSize) naik sebesar satu satuan, sementara varaibel lainnya diasumsikan tetap, maka manajemen laba (Y) akan mengalami peningkatan sebesar 0,409 satuan. Nilai koefisien variabel asimetri informasi (SPREAD) sebesar 0,103 menunjukan bahwa jika asimetri informasi (SPREAD) naik sebesar satu satuan, sementara varaibel lainnya diasumsikan tetap, maka manajemen laba (Y) akan mengalami peningkatan sebesar 0,103 satuan. Nilai koefisien variabel leverage (LEV) sebesar 0,005 menunjukan bahwa jika leverage (LEV) naik sebesar satu satuan, sementara variabel lainnya diasumsikan tetap, maka manajemen laba (Y) akan mengalami peningkatan sebesar 0,005 satuan.

Tabel 4, menunjukkan nilai adjusted $\mathrm{R}^{2}$ sebesar 0,352. Hal ini berarti 35,2 persen dari variansi manajemen laba perusahaan manufaktur tahun 2017-2019 dijelaskan oleh variansi DDW, DKW, KAW, ukuran perusahaan, dan asimetri informasi, sedangkan sisanya sebesar 64,8 persen dipengaruhi oleh variansi faktor lain yang tidak dimasukkan dalam model penelitian. Nilai sig $F_{\text {hitung }}=0,000<a=$ 0,005 . Ini berarti variabel independen merupakan penjelas yang signifikan secara statistik pada manajemen laba perusahaan manufaktur yang terdaftar di BEI periode 2017-2019.

Tabel 4. menunjukkan nilai koefisien regresi variabel dewan direksi wanita 0,144 dan nilai signifikasi 0,003 lebih kecil dari 0,05 $(0,003>0,05)$ yang berarti keberadaan dewan direksi wanita dalam jajaran dewan direksi memberikan pengaruh positif signifikan terhadap praktik manajemen laba. Hasil penelitian ini bertentangan dengan penelitian yang dilakukan oleh Gavious et al. (2012), Lakhal et al. (2015) serta Barber \& Odean (1999) namun sejalan dengan penelitian yang dilakukan Na \& Hong (2017) yang tidak dapat menemukan bukti bahwasanya CEO wanita cenderung melakukan earnings management yang agresif. Penelitian Na \& Hong (2017) juga menjelaskan bahwa perempuan tampaknya tidak terlibat dalam meminimalsir manajemen laba meskipun ada insentif yang kuat untuk melakukannya.

Tabel 4, menunjukkan nilai koefisien regresi variabel dewan komisaris wanita sebesar 0,107 dan nilai signifikasi yaitu 0.004 lebih kecil dari 0,05 $(0,004<$ $0,05)$ yang berarti keberadaan dewan komisaris wanita dalam jajaran dewan direksi tidak mampu meminimalisir praktik manajemen laba. Hasil penelitian ini bertentangan dengan penelitian yang dilakukan oleh Arbain et al. (2015) namun sejalan dengan penelitian yang dilakukan oleh Razak dan Helmy (2020) yang menjelaskan bahwasanya dewan komisaris wanita dalam jajaran dewan komisaris tidak dapat memberikan pengaruh yang secara signifikan terhadap praktik manajemen laba. Keberadaan wanita dalam jajaran dewan komisaris perusahaan belum dapat melakukan pengawasan secara optimal untuk mencegah terjadinya praktik manajemen laba. Wanita dikenal dengan sifat komunal yang cenderung behati-hati dan tidak tergesa-gesa serta lebih kearah menghindari risiko yang dapat menjatuhkan perusahaan di dunia bisnis sehingga membuat wanita menjadi lebih pasif di dalam pengambilan keputusan. Implikasinya, keberadan wanita tidak mengurangi praktik manajemen laba.

Tabel 4, menunjukkan nilai koefisien regresi variabel komite audit wanita sebesar 0.345 dan nilai signifikasi yaitu 0.000 lebih kecil dari 0,05 $(0,000<0,05)$ 
yang berarti keberadaan komite audit wanita dalam jajaran dewan direksi tidak memberikan pengaruh yang signifikan terhadap praktik manajemen laba. Hasil penelitian ini bertentangan dengan penelitian yang dilakukan oleh Sun \& Liu (2014) dan Na \& Hong (2017) namun selaras dengan hasil penelitian dari Ye et al. (2010), Medyawati \& Dayanti (2016), Novilia \& Nugroho (2016) bahwa keberadaaan wanita dalam komite audit tidak menurunkan praktik manajemen laba dalam perusahaan. Hal ini dapat diartikan bahwa baik wanita ataupun pria dalam jajaran komite audit akan memberikan kualitas laba yang sama.

Tabel 4, menunjukkan nilai koefisien regresi variabel ukuran perusahaan 0,409 dan nilai signifikasi yaitu 0,000 lebih kecil dari $0,00(0,000<0,05)$ yang berarti ukuran perusahaan berpengaruh positif signifikan terhadap manajemen laba sehingga semakin besar ukuran perusahaan, maka semakin besar pula praktik manajemen laba yang terjadi. Hasil penelitian ini sesuai dengan penelitian yang dilakukan Ali et al. (2015), Astari \& Suryanawa (2017), Susanto \& Christiawan (2016) dan Nalarreason et al. (2019) yang menunjukan bahwa perusahaanperusahaan yang lebih besar memiliki dorongan yang lebih besar untuk melakukan perataan laba dibandingkan dengan perusahaan kecil, karena memiliki biaya politik lebih besar. Biaya politik muncul dikarenakan profitabilitas perusahaan yang tinggi dapat menarik perhatian media dan konsumen. Perusahaan besar seringkali menjadi perhatian dan mendapat banyak tekanan dari banyak pihak investor sehingga seringkali mendapatkan tuntutan untuk memiliki informasi laba yang positif. Tuntutan tersebut seringkali menjadikan manajemen berusaha untuk melaporkan laba lebih tinggi, dengan begitu maka manajemen melakukan tindakan manajemen laba untuk memanipulasi labanya agar menarik investor.

Tabel 4, menunjukkan bahwa nilai koefisien regresi variabel asimetri informasi sebesar 0,103 dan nilai signifikasi yaitu 0,001 lebih kecil dari 0,05 (0,001 $<0,05)$ yang berarti asimetri informasi berpengaruh positif signifikan terhadap manajemen laba. Penelitian ini sejalan dengan penelitian yang dilakukan oleh Mahawyahrti \& Budiasih (2017) dan Mustikawati \& Cahyonowati (2015) yang menyatakan bahwa semakin tinggi asimetri informasi yang terjadi antara agent dengan principal, maka semakin besar kemungkinan tindakan praktik manajemen laba yang dilakukan oleh agent dalam perusahaan.

Tabel 4, menunjukkan bahwa variabel kontrol yang digunakan dalam penelitian ini adalah leverage yang diukur dengan menggunakan Debt to Equity Ratio (DER). Berdasarkan hasil uji regresi yang telah dilakukan ditemukan bahwa variabel leverage berpengaruh positif tidak signifikan terhadap manajemen laba. Hal ini berarti nilai leverage suatu perusahaan tidak dapat digunakan sebagai indikator praktik manajemen laba yang terjadi pada sebuah perusahaan.

\section{SIMPULAN}

Keberadaan dewan direksi wanita pada Corporate Governance tidak mampu meminimalisir praktik manajemen laba. Keberadaan dewan direksi wanita pada penelitian ini diproksikan dengan presentase dewan direksi wanita dalam struktur dewan direksi. Hal ini menunjukkan bahwa gender diversity pada Corporate Governance suatu perusahaan tidak dapat digunakan sebagai indikator yang menentukan tinggi rendahnya praktik manajemen laba. 
Keberadaan dewan komisaris wanita pada Corporate Governance tidak mampu meminimalisir praktik manajemen laba. Keberadaan dewan komisaris wanita pada penelitian ini diproksikan dengan presentase dewan komisaris wanita dalam struktur dewan komisaris. Hal ini menunjukkan bahwa gender diversity pada Corporate Governance suatu perusahaan tidak dapat digunakan sebagai indikator yang menentukan tinggi rendahnya praktik manajemen laba

Keberadaan komite audit wanita pada Corporate Governance tidak mampu meminimalisir praktik manajemen laba. Keberadaan komite audit wanita pada penelitian ini diproksikan dengan presentase komite audit wanita dalam susunan komite audit. Hal ini menunjukkan bahwa gender diversity pada Corporate Governance suatu perusahaan tidak dapat digunakan sebagai indikator yang menentukan tinggi rendahnya praktik manajemen laba.

Ukuran perusahaan mampu mempengaruhi praktik manajemen laba. Ukuran perusahaan yang diproksikan dengan logaritma natural dari total aktiva perusahaan. Hal ini menunjukan bahwa semakin besar ukuran perusahaan maka semakin besaar juga kemungkinan untuk agent melakukan praktik manajemen laba. Asimetri informasi mampu mempengaruhi praktik manajeman laba. asimetri informasi diproksikan dengan relative bid-ask spread. Hal ini menunjukkan bahwa tingginya asimetri informasi yang terjadi antara principal dengan agent, maka semakin besar kemungkinan tindakan praktik manajemen laba yang dilakukan oleh agent dalam perusahaan.

\section{REFERENSI}

Ali, U., Noor, M., Khurshid, M. K., \& Mahmood, A. (2015). Impact of Firm Size on Earnings Management: A Study of Textile Sector of Pakistan. SSRN Electronic Journal, 7(28), 47-56. https:// doi.org/10.2139/ssrn.2698317

Arbain, J., Azizah, N., \& Sari, I. N. (2015). Pemikiran Gender Menurut Para Ahli: Telaah atas Pemikiran Amina Wadud Muhsin, Asghar Ali Engineer, dan Mansour Fakih. Sawwa: Jurnal Studi Gender, 11(1), 75-94. https://doi.org/10.21580/sa.v11i1.1447

Astari, A. A. M. R., \& Suryanawa, I. K. (2017). Faktor-Faktor Yang Mempengaruhi Manajemen Laba. E-Jurnal Akuntansi, 20(1), 290-319.

Barber, B. M., \& Odean, T. (1999). Boys will be Boys: Gender, Overconfidence, and Common Stock Investment. SSRN Electronic Journal, September, 1-37. https://doi.org/10.2139/ssrn.139415

Dechow, P. M., Sloan, R. G., \& Sweeney, A. P. (1995). Detecting earning Management. In The accounting Review (Vol. 70, Issue 20, pp. 193-225).

Eagly, A. H., \& Karau, S. J. (2002). Role congruity theory of prejudice toward female leaders. Psychological Review, 109(3), 573-598. https://doi.org/10.1037/0033-295X.109.3.573

FCGI. (2001). Peranan Dewan Komisaris dan Komite Audit dalam Pelaksanaan Corporate Governance (Tata Kelola Perusahaan).

Gavious, I., Segev, E., \& Yosef, R. (2012). Female directors and earnings management in high-technology firms. Pacific Accounting Review, 24(1), 4-32. https://doi.org/10.1108/01140581211221533

Gul, F. A., Srinidhi, B., \& Ng, A. C. (2011). Does board gender diversity improve the informativeness of stock prices? Journal of Accounting and Economics, 51(3), 
314-338. https://doi.org/10.1016/j.jacceco.2011.01.005

Hartono, J. (2007). Teori Portofolio Dan Analisis Investasi (11th ed.). BPFE.

Healy, P. M., \& Wahlen, J. M. (1999). A Review Of The Earnings Management Literature And Its Implications For Standard Setting. Accounting Horizon, 12(4), 1-34.

Jensen, M. C., \& Meckling, W. H. (1976). Theory Of The Firm: Managerial Behavior, Agency Costs And Ownership Structure. Journal of Financial Economics, 3, 305360.

Lakhal, F., Aguir, A., Lakhal, N., \& Malek, A. (2015). Do women on boards and in top management reduce earnings management? Evidence in France. Journal of Applied Business Research, 31(3), 1107-1118. https://doi.org/10.19030/jabr.v31i3.9236

Louann Brizendine, M. D. (2010). The Male Brain. Broadway Books.

Lupita, I. W., \& Meiranto, W. (2019). Pengaruh Surplus Arus Kas Bebas, Ukuran Perusahaan, Leverage, Dan Kualitas Audit Terhadap Manajemen Laba. Diponegoro Journal of Accounting, 7(4), 1-11.

Mahawyahrti, T., \& Budiasih, G. N. (2017). Asimetri Informasi, Leverage, dan Ukuran Perusahaan pada Manajemen Laba. Jurnal Ilmiah Akuntansi Dan Bisnis, 11(2), 100-110. https:/ / doi.org/10.24843/jiab.2016.v11.i02.p05

Medyawati, H., \& Dayanti, A. (2016). Pengaruh Ukuran Perusahaan Terhadap Manajemen Laba: Analisis Data Panel. Jurnal Ilmiah Ekonomi Bisnis, 21(3), 142152. https://doi.org/10.35760/eb.

Midiastuty, P. P., \& MACHFOEDZ, M. (2003). Analisis Hubungan Mekanisme Corporate Governance Dan Indikasi Manajemen Laba. Simposium Nasional Akuntansi VI, 176-199.

Mustikawati, A., \& Cahyonowati, N. (2015). Pengaruh Asimetri Informasi Terhadap Manajemen Laba Dengan Ukuran Perusahaan Sebagai Variabel Pemoderasi. Diponegoro Journal of Accounting, 4(4), 1-8.

$\mathrm{Na}, \mathrm{K} .$, \& Hong, J. (2017). CEO gender and earnings management. Journal of Applied Business Research, 33(2), 297-308. https:/ / doi.org/10.19030/jabr.v33i2.9902

Nalarreason, K. M., T, S., \& Mardiati, E. (2019). Impact of Leverage and Firm Size on Earnings Management in Indonesia. International Journal of Multicultural and Multireligious Understanding, 6(1), 19-24. https://doi.org/10.18415/ijmmu.v6i1.473

Novilia, O., \& Nugroho, P. I. (2016). Pengaruh Manajemen Puncak Wanita Terhadap Manajemen Laba. Dinamika Akuntansi, Keuangan Dan Perbankan, $5(1), 27-45$.

Octaviani, S., \& Kartikaningdyah, E. (2019). Effect of Corporate Governance (Woman'S Executive Board), Company Size and Leverage on Profit Management. Journal of Applied Managerial Accounting, 3(1), 51-65. https:// doi.org/10.30871/jama.v3i1.955

Peni, E., \& Vähämaa, S. (2010). Female executives and earnings management. Managerial Finance, 36(7), 629-645. https:// doi.org/10.1108/03074351011050343

Prasetyo, D. (2018). Pengaruh Good Corporate Governance, Kualitas Audit, Dan Asimetri Informasi Terhadap Manajemen Laba. Jurnal Ilmiah Mahasiswa FEB Universitas Brawijaya, 6(1). https://doi.org/10.1017/CBO9781107415324.004 
Razak, B., \& Helmy, H. (2020). Pengaruh Dewan Direksi Wanita, Dewan Komisaris Wanita Dan Kualitas Pengungkapan. Jurnal Eksplorasi AKuntansi, 2(4), 34343451.

Ronikusuma, F. Y., \& Hadiprajitno, P. T. B. (2019). Pengaruh Surplus Arus Kas Bebas, Ukuran Perusahaan, Leverage, Dan Kualitas Audit Terhadap Manajemen Laba. Diponegoro Journal of Accounting, 7(4), 1-15.

Schipper, K. (1986). Schipper, 1989.pdf. In Accounitng horizons (Vol. 3, pp. 91-102).

Sun, J., \& Liu, G. (2014). Audit committees' oversight of bank risk-taking. Journal of Banking and Finance, 40(1), 376-387. https:// doi.org/10.1016/j.jbankfin.2013.12.015

Susanto, S., \& Christiawan, Y. J. (2016). Pengaruh earnings management terhadap firm value. Business Accounting Review, 4(1), 205-216.

Tierney, H. (1999). Women's Studies Encyclopedia: G-P. 640. http:/ / books.google.co.id/books?id=2bDxJW3x4f8C

Wiagustini, N. L. P. (2014). Manajemen Keuangan (1st ed.). Udayana University Press.

World Economic Forum. (2019). Global Gender Gap Report 2020: Insight Report. http://www3.weforum.org/docs/WEF_GGGR_2020.pdf

Ye, K., Zhang, R., \& Rezaee, Z. (2010). Does top executive gender diversity affect earnings quality? A large sample analysis of Chinese listed firms. Advances in Accounting, 26(1), 47-54. https:// doi.org/10.1016/j.adiac.2010.02.008 